\title{
O "JOVEM" LUKÁCS: TRÁGICO, UTÓPICO E ROMÂNTICO?
}

\author{
Ester Vaisman* \\ emjchasin@uol.com.br
}

\begin{abstract}
RESUMO Dada o caráter polêmico da trajetória intelectual do "Jovem" Lukács, sobretudo em relação às obras A alma e as formas $e$ A teoria do romance, o objetivo central do presente artigo é delinear com largos traços a trajetória de Lukács em sua fase de juventude, tendo como base seus próprios textos e depoimentos, com vistas a problematizar certas atribuições feitas a esse importante período de sua produção intelectual.
\end{abstract}

Palavras-Chave Estética lukácsiana, Romantismo, Ciências do Espírito

ABSTRACT Given the controversial character of "Young” Lukács' intellectual path, essentially concerning to the works The Soul and The Forms and Theory of the Romance, the central objective of the present article is to delineate with wide lines the path of Lukács in his youth phase (based on their own texts and testimonies) and, thus, to discuss certain attributions done for this important period of his intellectual production.

Keywords Lukács's aesthetics, Romanticism, Spirits'Science

* Professora do Departamento de Filosofia da UFMG. Artigo recebido em 15/09/05 e aprovado em 15/11/05.

KRITERION, Belo Horizonte, $\mathrm{n}^{0}$ 112, Dez/2005, p. 293-310 
Desde logo, é necessário chamar a atenção do leitor para o fato de que Lukács pode ser considerado como um dos pensadores mais marcantes da cultura marxista contemporânea. Tal avaliação, diga-se de passagem, não é fruto apenas de seus intérpretes, que, de um modo ou de outro, vieram a se alinhar em torno da obra do pensador húngaro, mas também de seus próprios adversários.

Não é nosso objetivo aqui deslindar em toda sua complexidade a evolução intelectual e política do autor em tela, mesmo porque "a evolução intelectual de Georg Lukács oferece uma imagem singular da formação e do devir de uma personalidade nas condições agitadas de um século não menos singular, por sua complexidade e pelo caráter dramático de sua história". ${ }^{1}$

Ademais, que outro pensador contemporâneo foi capaz de renunciar crítica e deliberadamente, como ele fez por diversas vezes, ao prestígio de obras consagradas? Renúncia que chegou ao total divórcio delas, a ponto mesmo de manifestar completa desidentidade autoral por textos que teriam feito, cada um de per se, a inconfessa e sempre almejada glória de carreira de qualquer um, inclusive dos melhores e mais respeitáveis.

Esse desapego, sinônimo de enorme exigência para consigo mesmo, que nunca declinou em arrogância ou pedantismo, nem em autoproclamações de méritos ou em bravatas de auto-suficiência, em que pese a imensa solidão teórica a que esteve constrangido seu trabalho, essa aguda consciência da responsabilidade de ser homem e intelectual aflorou muito cedo, logo aos primeiros passos.

Tem com certeza sabor de arroubo juvenil a decisão, aos dezoito anos (1903), de queimar todos os seus escritos literários - alguns dramas à la Ibsen e Hauptmann (redigidos nos três anos anteriores), que em definitivo julga então "horrivelmente ruins". Gesto incomum, exatamente porque juvenil, e ainda mais porque dele nasceu "um critério secreto para estabelecer as fronteiras da literatura, qual seja: era ruim aquilo que eu também poderia escrever. A literatura começa onde tenho a impressão de não poder escrever a obra em questão". ${ }^{2}$

Exatamente por essas razões, nosso propósito é bem mais modesto: pretende-se aqui delinear com largos traços a trajetória de Lukács em sua fase de juventude, tendo como base seus próprios textos e depoimentos, com o objetivo de problematizar certas atribuições feitas a esse importante período de sua produção intelectual.

1 TERTULIAN. L'évolution de la pensée de Georg Lukács. L'Homme et la Societé, n. 20, p. 15.

2 LUKÁCS. Pensamento vivido-Autobiografia em diálogo, p. 32. 
Bem menos drástico do que o fato relatado acima, não por isso deixando de ser muito mais significativo, é o episódio que envolve o primeiro livro de Lukács, História da evolução do drama moderno, cuja primeira versão foi finalizada aproximadamente quatro anos depois. Ainda estudante da Faculdade de Letras de Budapeste, Lukács empreende, de 1904 a 1909, um amplo projeto no campo teatral, através da fundação da Thalia Bühne (Thalia Gesellschaft), da qual foi um dos diretores. É a sua participação no radicalismo intelectual húngaro, que havia identificado no teatro o instrumento mais é apropriado para promover a "subversão das consciências" que tinha por alvo. Desse empenho concreto no campo artístico, da reflexão de inúmeras questões dramatúrgicas praticamente afrontadas é que tem origem $O$ drama moderno. Premiado pela obra em 1908, Lukács entra em desespero: "Não considerava aquela gente toda (o júri de premiação) competente para julgar o assunto. Portanto, a articulação do prêmio a mim significava que deveria existir alguma coisa problemática em meu livro." É muito expressivo, do traço lukacsiano aqui posto em evidencia, que ele confesse que "procurava em vão esse algo problemático", e que, no caso, a ajuda tenha vindo de Leo Popper, a quem considerava "talvez o maior talento" que encontrou em sua vida e de quem afirma também que "possuía um senso infalível para a qualidade". Ajuda que consistiu não da indicação do que não funcionava no livro, mas, ao contrário, do que "funcionava bem". Bem mais adiante, sem desmerecer em nada o auxílio de Leo Popper, tornando a avaliar a obra, já em outro diapasão analítico, recordou: "a filosofia sotoposta a meu livro sobre o drama é, na verdade, a filosofia de Simmel", ${ }^{3}$ o que, no contexto da historiografia literária húngara do começo do século, no entanto, significava um contraste total com a mesquinhez das variantes positivistas tanto do oficialismo literário como de seus opositores, entre os quais também se manifestava, em sua estreiteza, o impressionismo subjetivista a título de posição estética.

Em verdade, o que movia Lukács desde o início era a busca de uma forma de interpretação das manifestações literárias que não fosse mera abstração de seus conteúdos peculiares. Donde, na contraposição teórica em que se encontrava e sob a aderência ao neokantismo, não ter ido além, naquela época, da equação armada em História da evolução do drama moderno: a da pura síntese intelectual entre sociologia e estética, sob amparo e sustentação do pensamento de Simmel, em lugar de partir "das relações diretas e reais entre a sociedade e a literatura", como dirá no Prefácio a Arte e Sociedade; onde afirma também

3 LUKÁCS. Pensamento vivido - Autobiografia em diálogo, p. 36. 
que "não pode surpreender que de uma postura tão artificiosa tenham derivado construções abstratas", sempre insatisfatórias, até mesmo quando atinam com alguma determinação verdadeira.

Em suma, o que então praticara - e "funcionava bem", indiretamente o pusera em desespero, sem que atinasse com a natureza do problema - fora um brilhante exercício de ciência do espírito. A mero título de ilustração, vale reproduzir uma passagem do Preâmbulo da obra: "A forma autêntica do artista autêntico é a priori: é uma forma constante em face das coisas, um algo sem o qual ele nem mesmo as poderia perceber. (...) Dizíamos: a forma é a realidade social, participa vivamente da vida espiritual". ${ }^{4}$ Com abstractivismos desse tipo - a forma como um a priori social —, que buscam exatamente amalgamar estética e sociologia (ou melhor, uma certa sociologia), não é impossível brilhar, mas deixa-se fora de alcance a especificidade literária, bem como o preciso conteúdo humano-social que ela refigura em cada expressão efetiva. Para quem aspirava o inverso e praticara o contrário do pretendido, havia mesmo com que se desesperar, não obstante o talento revelado na confecção do livro, que fora reconhecido e laureado.

Já integrado à sua estrutura de personalidade, o "exame de consciência" alcançará depois, sucessivamente, dois livros famosos: A alma e as formas (1911) e A teoria do romance (1914/15), obras do trânsito lukacsiano de Kant a Hegel que culmina na última. É o percurso que o leva, sem abandonar o território das assim chamadas ciências do espírito (Dilthey, Simmel, Weber), da filosofia e da nascente sociologia alemã, de Simmel, para uma forma da ciência do espírito acoplada ou traspassada pelo hegelianismo, responsável pela urdidura de A alma e as formas e com acentuação maior de A teoria do romance.

Estas, é de lembrar, foram obras muito bem recebidas, inclusive por expoentes máximos da cultura alemã de então: Thomas Mann foi dos leitores que aprovaram A teoria do romance e anteriormente afirmara que A alma e as formas era "a coisa mais extraordinária que jamais fora dita sobre este tema paradoxal"; Max Weber, por sua vez, que não só exerceu, naquele momento, influência sobre Lukács, mas também sofreu a influência deste, especialmente no que tange à reflexão das questões éticas, além de apreciar esses dois livros, mostrou-se muito sensibilizado por outro texto lukacsiano daquela época Sobre pobreza do espírito (1911), ao qual se referiu como um "ensaio profundamente artístico" no qual "à força criativa do amor é concedido o direito

4 LUKÁCS. Dalla Prefazione a Storia dello sviluppo del Drama Moderno. In: Scritti di Sociologia della Literatura, p. 77-78. 
de infringir a norma ética". E Max Dvorak, historiador tcheco da arte, chegou mesmo a considerar A teoria do romance como o trabalho mais importante no âmbito da vertente configurada pelas ciências do espírito. ${ }^{5} \mathrm{E}$, já nos princípios dos anos sessenta, Lucien Goldmann dirá que A alma e as formas "por numerosas razões marca uma data essencial na história do pensamento contemporâneo. Em primeiro lugar, porque depois de muitos anos de filosofia acadêmica, Lukács recuperava nessa obra a grande tradição da filosofia clássica, colocando no centro de suas preocupações o problema das relações entre a vida humana e os valores absolutos". E ainda mais, que com essa obra "provavelmente começa na Europa o renascimento filosófico que se seguiu à Primeira Guerra Mundial", de modo que Lukács "foi o primeiro no século XX a colocar os problemas que dominam o pensamento filosófico que desde a morte de Hegel havia, mais ou menos, desaparecido da consciência européia". Sobre A teoria do romance, Goldmann não é menos aprovador e enfático. É também em sua Introdução aos Primeiros escritos de Georg Lukács que se lê:

(...) na Teoria do romance estuda as grandes formas épicas que, contrariamente às que havia elegido precedentemente, são realistas, isto é, descansam, se não sobre uma acepção da realidade, pelo menos sobre uma atitude positiva em relação a uma realidade possível, cuja possibilidade está fundada no mundo existente. (...) Assim, numa época em que a crise da sociedade ocidental se tornara manifesta a todos aqueles que, poucos anos antes, não haviam sequer suspeitado dela, Georg Lukács, que havia sido um dos primeiros a descobri-la, afirma a categoria da esperança realista e esboça, por isso mesmo, a categoria central de seu pensamento ulterior, a categoria de possibilidade objetiva. ${ }^{6}$

Sucesso e boa acolhida, no entanto, que não impediram Lukács, em suas avaliações, de denunciar A teoria do romance precisamente como produto tópico das ciências do espírito, por isso mesmo comprometida pelo seu método ilusionista, que operava através do estabelecimento intuitivo de abstrações infundadas, a partir das quais, por dedução, eram abordados os fenômenos singulares. O mesmo ocorrendo já quanto ao passo anterior desse andamento, que se esforçava por dar as costas ao modo abstrato-especulativo de entender e examinar as formações literárias e de refletir sobre os problemas vitais da existência humana que elas encerram.

\section{Em A teoria do romance,}

a tipologia dos romances foi elaborada a partir de um esquema abstrato: o tipo do romance onde a consciência do herói é mais estreita que a zona da realidade objetiva,

5 TERTULIAN. L'évolution de la pensée de Georg Lukács. L'Homme et la Societé, n. 20, p. 18.

6 GOLDMANN. Introduzione a Teoria del Romanzo, p. 25. (grifos no original) 
engendrando a atitude do "idealismo abstrato" (Dom Quixote) e aquele do romance onde a consciência do herói, por sua riqueza interior, ultrapassa a realidade (o romance da desilusão, exemplificado entre outros, pela Educação sentimental de Flaubert). ${ }^{7}$

É oportuno ressaltar, para que não reste qualquer dúvida quanto à natureza das auto-avaliações lukacsianas, que sua insatisfação e completo distanciamento de A alma e as formas é extremamente precoce. Mal havia transcorrido um ano de sua publicação, manifesta já total indiferença pela obra; sentimento que veio a reiterar, ao longo de toda a vida, em relação a todos os seus "trabalhos intelectuais já superados".

É em uma carta (25/9/1912) à escritora Margarethe Susmann (von Bandemann), que três semanas antes havia publicado uma resenha de A alma e as formas, que podemos apreciar por inteiro a posição e o comportamento de Lukács, em flagrante tão característico quanto ilustrativo, especialmente porque distante quase vinte anos de sua desembocadura propriamente marxista.

O pensador húngaro principia por declarar, gentilmente, que quase tudo que havia de essencial em seu livro fora compreendido e formulado com força e segurança pela resenhista, como poucos o haviam feito até então; agradece muito que M. Susmann tenha "apreendido o momento mais importante do meu caminho: o meu conceito de forma" e externa também muita satisfação porque a autora do pequeno artigo ressaltara "o papel da história, bem como a importância dos ensaios inicial (Sobre a essência e a forma do ensaio) e final (Metafísica da tragédia)" no livro sumariado ${ }^{8}$.

Todavia, logo à frente, já naquele longínquo momento, Lukács explicita, tipicamente, em face dos comentários da resenhista, um "ponto de discordância", que muito menos censura uma interpretação errônea do livro tal como ele é do que denuncia um defeito de sua própria obra. Para o autor de A alma e as formas, Margarethe Susmann converte em "traço característico" aquilo que é "condição" do ensaio, ou seja: "a ética da forma ensaística é o desespero, que nasce do antiqüíssimo dissídio interno dessa forma". Em outros termos, "a inevitável falta de conclusão última é o desespero deste livro". A esse admitido comprometimento formal da obra, Lukács contrapõe, de imediato, a seguinte consideração sintomática, relativa à necessidade de conclusão: "mas — ao menos como o sinto hoje - ela é mirada já algumas vezes de longe". E desenvolve a crítica, dizendo que Susmann "considera essa meta inatingível e a sua inatingibilidade um 'fato' da filosofia da história, uma característica do nosso tempo", para replicar duramente e com muita ênfase:

7 TERTULIAN. L'évolution de la pensée de Georg Lukács. L'Homme et la Societé, n. 20, p. 23.

8 LUKÁCS. Epistolário (1902-1917), p. 302-305. 
Para mim (inclusive no momento em que escrevi os ensaios inicial e final) a meta está diante de mim perfeitamente atingível. todavia, se eu não a atingisse, isso não seria um "fato" para extrair conclusões acerca da essência do sentimento metafísico, mas uma sentença a meu respeito (e somente a meu respeito), sobre meu não chamamento à filosofia. ${ }^{9}$

De fato, é indubitável a recusa lukacsiana da inconcludência ensaística, tanto quanto sua franca perseguição a uma verdade única e real, mesmo que à época a identificasse abstratamente a um sistema absoluto, como testemunham suas próprias palavras:

Se refutamos a possibilidade de responder a pergunta última, que decide tudo, todas as nossas categorias perdem por isso seu significado constitutivo e cada enunciado nosso acerca daquilo que está além e fora de nós permanece em nós, torna-se reflexivo, nós perdemos a decisiva responsabilidade pelo rigor dos conceitos, que de fato pode se dar pelo enquadramento hierárquico no sistema absoluto. ${ }^{10}$

É este, na realidade, o verdadeiro problema da crítica lukacsiana a A alma $e$ as formas, pouco depois de sua publicação: a inconcludência da obra determina sua indiferença por ele, pois ao contrário do que gostariam de ver alguns de seus intérpretes, não é de seu espírito, nem mesmo em sua fase idealista mais exacerbada, exultar no gozo da patinação impotente entre contrapostos "equivalentes" e indeterminações "intransponíveis". Para ele, já naquele momento, a incapacidade de concluir é uma debilidade muito grande e muito desconfortável, que confessa, ao mesmo tempo que anseia por ultrapassar. É o que esclarece à resenhista, afirmando que, nos ensaios de $A$ alma e as formas, não deixou nunca de procurar fugir ao perigo da invalidação da questão última, de modo que "tudo que neles há de — aparentemente muito subjetivo, 'poético', fragmentário nasceu do esforço de tentar ser unívoco, incisivo, responsável - sem possuir, sem ainda, a responsabilidade evidente do sistema completo". ${ }^{11}$

É óbvio, portanto, que seja, no mínimo, extremamente problemático atribuir a Lukács, mesmo ao tempo dessa obra, um mero e simples pathos trágico, e, muito mais do que isso, estender tal estado de espírito para seus futuros trabalhos.

Para efeito, no entanto, do que aqui é mostrado - sua precoce incompatibilização com A alma e as formas —, basta arrematar com o último trecho da carta a Margarethe Susmann:

9 LUKÁCS. Epistolário (1902-1917), p. 302-305.

10 Idem.

11 Idem. (grifos no original) 
Em realidade, por este livro, que provavelmente é menos do que um início, não deveria esperar ser entendido, e decerto não o poderia exigir (como pode pretender um ato do espírito que seja objetivo, concluso). Está, de fato, repleto de saber intuitivo sobre aquilo que (por mim) virá, pensamentos cujo caminho e fim somente agora vão se tornando claros, - quando o conjunto e sua forma se tornaram para mim absolutamente estranhos. ${ }^{12}$

A última frase, grifada por mim, foi retomada por Lukács cinqüenta e cinco anos depois de escrita, para com ela evidenciar que sempre se tornou indiferente em relação a obras superadas. Está inserida no Volume II de suas Obras completas, precisamente no Prólogo de 1967, o que lhe confere, pela importância do texto e pela proximidade da morte do autor, expressividade ainda maior. o que deve prevalecer, a força de um testemunho meio secular, muito bem articulado, ou alguma grosseira imputação especulativa das muitas com que a mediocridade lhe tem brindado?

O diagnóstico que oferece sobre A teoria do romance, por sua vez, aludido anteriormente, não só não exclui esta obra do terreno achatado das abstrações na prática da análise literária, como até mesmo confere a ela dimensão de exemplaridade na ordem dessa debilidade analítica. Ou, posto em suas palavras: "A teoria do romance é um representante típico das 'ciências do espírito' e não remete para além das limitações metodológicas destas." ${ }^{13} \mathrm{O}$ que é tanto mais significativo, se não se põe de lado que o talhe da crítica lukacsiana é consistentemente matizado, ou seja, não deixa de discernir e apontar aspectos válidos, conquistas parciais efetivadas nesse livro como nos anteriores. Discernimento, todavia, que não o induz, como é tão freqüente, a fragilizar a reflexão crítica e, a partir disso, resvalar para o fosso comum da relativização de méritos e deméritos. Ao contrário, é sobre a malha diferenciada destes que faz sobressair a franqueza do resultado:

O autor de A teoria do romance estava em busca de uma dialética geral dos gêneros, fundada na essência das categorias estéticas, na essência das formas literárias e também historicamente; uma dialética que tendia para uma vinculação entre categoria e história mais íntima do que encontrava em Hegel; buscava a permanência na mudança, a transformação interior dentro da permanente validade da essência; buscava a compreensão disso. Porém, seu método continuava sendo sumamente abstrato em muitos pontos, precisamente em contextos de grande importância, e continuava isolado das concretas realidades histórico-sociais. Por isso (...) leva o autor muito freqüentemente a construções arbitrárias. ${ }^{14}$

2 LUKÁCS. Epistolário (1902-1917), p. 302-305.

13 LUKÁCS. Prólogo a La Teoria de la Novela. In: Obras completas, v. I, p. 285.

14 Ibidem, p. 287. 
O reconhecimento dos matizes a propósito de A teoria do romance alcança inclusive as determinações extra-teóricas da gênese desse livro e, com isso, torna ainda mais precisa a fisionomia intelectual e vivencial do seu autor quando da elaboração do texto.

O estalar da Guerra de 1914 e seu efeito sobre a intelectualidade de esquerda, ao ser assumida pela social-democracia, é que determinam o projeto de redação de A teoria do romance. Esta "nasceu de um estado de espírito de permanente desespero diante da situação mundial", ${ }^{15}$ diz Lukács, que, por mais de uma vez, lançou mão de uma fórmula de Fichte para caracterizar a imagem que nutria daquele tempo: "época da pecaminosidade consumada". ${ }^{16}$ Essa visão infernal de uma Europa sem brechas e sem horizontes, tecida de pessimismo eticamente modulado, faz do Lukács de A teoria do romance um utópico primitivo, para utilizar uma expressão quase idêntica à de seu próprio uso. De tal sorte que ele pode afirmar: "A teoria do romance não é conservadora, mas destruidora”. ${ }^{17} \mathrm{E}$ de forma mais concreta: “(...) metodologicamente, é um livro de história do espírito. Mas acho que é o único livro de história do espírito que não é de direita. Do ponto de vista moral, considero toda aquela época condenável e, na minha concepção, a arte é boa quando se opõe a esse decurso". ${ }^{18}$

Não há expressões mais fortes do que as do próprio filósofo húngaro para designar o utopismo sobre o qual assentava, então, sua reflexão e sua perspectiva prática: "primitivo", "sumamente ingênuo", "totalmente infundado" são os qualificativos que emprega sem qualquer embaraço. Toda sua esperança residira na cândida suposição de que "a queda das categorias mortas, antivitais, identificada com a do capitalismo, gerasse por si, sem mais, uma vida natural, digna do homem".$^{19}$ É algo como uma antecipação do que na década de 1920 viria a se firmar como uma idéia da reação: ultrapassar o mundo da economia através da movimentação social; e não deve escandalizar a lembrança de que, por suas características teóricas e práticas, a Segunda Internacional não está isenta de responsabilidade quanto à preparação dessa idealidade perversa. Mas, ao tempo da redação de A teoria do romance, a tônica estava do outro lado, e o quadro em germe daquele nódulo ideológico ainda não havia se clivado, de modo que ambos, quadro e tônica, pertenciam à generosidade equivocada de muitos daqueles que aderem, como Lukács, à extinção do prosaico mundo

15 LUKÁCS. Prólogo a La Teoria de la Novela. In: Obras completas, v. I, p. 182. 16 LUKÁCS. Pensamento vivido - Autobiografia em diálogo, p. 49.

17 LUKÁCS. Prólogo a La Teoria de la Novela. In: Obras completas, v. I, p. 290.

18 LUKÁCS. Pensamento vivido - Autobiografia em diálogo, p. 49.

19 LUKÁCS. Prólogo a La Teoria de la Novela. In: Obras completas, v. I, p. 290. 
burguês. Em outros termos, o inocente utopismo que subjaz a $A$ teoria do romance não é privilégio negativo de seu autor, mas, em sua esquálida figura, alimenta um texto que "expressa apesar de tudo uma corrente espiritual que, efetivamente, existia na época". ${ }^{20}$

Possuído por esse estado de ânimo, hoje quase inacreditável, e atado a uma ciência do espírito formalmente hegelianizada, sobre a qual ainda projetava elementos kierkegaardianos, além de conceber a realidade social pela lupa de Sorel, eis em concreto o polifrontismo teórico-político que (des)organiza a cabeça de Lukács aos trinta anos de idade. Contudo, mesmo nesse escândalo eclético-utópico, pleno e reconhecido, Lukács, nos seus reexames, é capaz de garimpar as distinções, localizando com toda propriedade o pólo de inflexão positiva: "A teoria do romance ficou no plano de um intento falido, seja na proposição como na execução, porém em suas intenções aproximava-se da saída adequada muito mais intensamente que seus contemporâneos." ${ }^{21} \mathrm{O}$ caráter dessa impulsão, que faz chegar mais perto do que ninguém da solução adequada está inscrito na própria obra (o que faz das "intenções" algo para além do mero desejo ou do voto piedoso), pois ela

delineia — é claro ainda dentro dos limites da literatura burguesa — a teoria do romance revolucionário. Naquela época não havia ainda qualquer coisa no gênero. Havia uma concepção do romance inspirada na ciência do espírito, conservadora tanto artística quanto ideologicamente. Minha Teoria do romance não era revolucionária no sentido do revolucionarismo socialista. No entanto, comparada à ciência literária e à teoria do romance da época, era revolucionária. ${ }^{22}$

A diferença entre os dois níveis revolucionários está em que

a época da pecaminosidade consumada de Fichte significa que a Europa havia decaído, daquela pseudo-solidez em que as pessoas viviam até 1914, ao nível onde se encontra hoje. Por conseguinte essa época da pecaminosidade total corresponde plenamente, em sentido negativo, à verdade. O que falta é o que Lênin desenvolveu a partir disso, isto é, que toda sociedade deve ser radicalmente transformada. (...) Em A teoria do romance isto ainda não existia. ${ }^{23}$

Em outras palavras, deliberadamente contundentes: em 1915 Lukács ignorava completamente Lênin, e estava muito aquém do Marx de 1844. Palavras fortes, aliás, que não podem surpreender, visto que os depoimentos lukacsianos vão

\footnotetext{
20 LUKÁCS. Prólogo a La Teoria de la Novela. In: Obras completas, v. I, p. 291.

21 Ibidem, p. 287.

22 LUKÁCS. Pensamento vivido - Autobiografia em diálogo, p. 49.

23 Ibidem, p. 50.
} 
sempre nessa direção, como, por exemplo, em Pensamento vivido, quando, ao invocar como documento o romance Os otimistas, de Ervin Sinkp, afirma:

Como era confusa a relação ideológica que os intelectuais daquela época mantinham com o comunismo. Dizer que eu fazia parte do grupo de pessoas que via as coisas com certa clareza revela a magnitude de tal confusão. Não pretendo exaltar a mim mesmo, só quero delinear o estado de ânimo geral. A formação marxista, mesmo de pessoas como eu, que tinham lido Marx, era muito limitada. ${ }^{24}$

Portanto, a contundência empregada visa muito mais à identificação crítica da época do que do autor. Tempo, em suma, como outros do gênero, que desfavorecem e embaraçam o acesso à lucidez; no caso, a ascensão para o pensamento marxiano de um talento íntima e espontaneamente inclinado, sem o saber, para as teses e resoluções desta vertente. Esta observação não é efeito de mera conjectura genérica.

A esse propósito, podem se identificar duas inclinações marcantes, desde o início presentes, e que se mantêm ao longo de todo seu itinerário juvenil, que matrizam ou traspassam a elaboração lukacsiana. Todavia, incapazes de atinar com as vias de sua efetiva encarnação, redundam a cada esforço em uma perversão de si mesmas. A tendência mais geral e do fundo, que orienta o homem e o pensador, é constituída pelo "ódio desdenhoso pela vida sob o capitalismo, que nasceu em mim quando era um adolescente" ${ }^{25}$; a outra, restrita à esfera teórica, almeja ultrapassar a mera confecção abstrata na atividade científica. Forças de impulsão, todavia, que se esboroam pela trajetória que são levadas a trilhar: o antiburguesismo visceral se esvai em utopismo ético, e o antiabstractivismo morde a própria cauda e reitera o objeto de sua própria repulsa.

No plano e na execução de A teoria do romance, os dois balizamentos e seus inversos comparecem de modo extremado, cada um pelo seu lado mais fraco potencializa o flanco mais débil do outro: Lukács sufoca na bruma de seu antiburguesismo impotente, e sucumbe, mais uma vez, aos ardis do abstractivismo — da abstração irrazoável, corrompida ademais pela sua transfiguração imperial —, que se reapresenta, apesar da nutrida aversão, com a aura do portador de soluções. As balizas, portanto, fundem-se.

A fusão de tendências de espírito contraditório é justamente o diagnóstico de Lukács a respeito de si mesmo enquanto autor de A Teoria do Romance.

É obrigatório remeter, aqui, à famosa passagem do Prólogo de 1962 a $A$ teoria do romance em que essa avaliação é categoricamente formulada: "Dito

24 LUKÁCS. Pensamento vivido - Autobiografia em diálogo, p. 56. 25 LUKÁCS. Prólogo (1967) a Histora y consciência de clase, p. XI. 
sumariamente, o autor de A teoria do romance tem uma concepção do mundo baseada numa fusão de ética 'de esquerda' e teoria do conhecimento (ontologia, etc.) 'de direita'". Para, menos de duas páginas adiante, quase ao final do Prólogo, tornar a ela sob expressão ainda mais concisa, na qual se celebrizou e difundiu: "síntese de ética de esquerda e epistemologia de direita". ${ }^{26}$

A fórmula, para Lukács, não pretende retratar um vício ou exotismo intelectual e anêmico de ordem meramente pessoal, mas indigitar uma posição agudamente falaciosa que, na Alemanha, foi apenas inaugurada por A teoria do romance. Equívoco grave que, em verdade, veio a se expandir bastante na produção ideológica dos anos vinte, à custa não mais de Lukács, mas de outros e diversos autores. O Prólogo explicita alguns: Bloch, Benjamin, Adorno em seus primórdios; e assinala que o fenômeno do "acoplamento da ética de esquerda e epistemologia de direita", na França, "era conhecido" e "tinha se destacado muito antes do que na Alemanha", vindo a ter "na pessoa de Sartre um influente representante desse tipo de atitude". ${ }^{27}$

Interessa reproduzir na íntegra o comentário a respeito de Bloch, porque é o mais completo e também porque este autor foi para Lukács uma verdadeira chave-mestra, na orientação de seu processo formativo. Em Pensamento vivido, declara o pensador húngaro em seus derradeiros meses de vida:

Bloch exerceu uma enorme influência sobre mim, pois com seu exemplo me convenceu de que é possível fazer filosofia à maneira tradicional. Até então, eu estava perdido em meio ao neokantismo do meu tempo, e aí encontrei em Bloch o fenômeno de alguém que filosofava como se toda filosofia atual não existisse, que era possível filosofar como Aristóteles ou Hegel. ${ }^{28}$

Reconhecimento que não desmente, nem é contraditório a sua crítica contundente do mesmo Bloch no Prólogo de 62, feita quase dez anos antes:

Que Ernst Bloch continue até agora inamovivelmente fiel à sua síntese de ética de esquerda e epistemologia de direita (como se pode ver em Philosophische Grundfragen I, Zur Ontologie des Noch-Nicht-Seins [Questões Filosóficas Fundamentais, I, Para a ontologia do Ainda-Não-ser], Frankfurt, 1961) honra, sem dúvida, a sua força de caráter, mas não pode suavizar o anacronismo de sua atitude teorética. ${ }^{29}$

No primeiro caso, Lukács mostra-se agradecido a Bloch, até o fim da vida, por ter conseguido se desembaraçar, em um momento crucial da juventude, do

26 LUKÁCS. Prólogo a La Teoria de la Novela. In: Obras completas, v. I, p. 291 e 293.

27 Ibidem, p. 291-292.

28 LUKÁCS. Pensamento vivido - Autobiografia em diálogo, p. 39.

29 LUKÁCS. Prólogo a La Teoria de la Novela. In: Obras completas, v. I, p. 292-293. 
gnosiologismo do começo do século. Foi, daí em diante, uma lição para toda sua existência intelectual: a abertura da senda ontológica que, apesar de todas as vicissitudes sofridas, acabou por se mostrar uma aquisição definitiva. No segundo caso, reprova em Bloch, o que o tom de censura fraterna só reforça, o padrão convencional da prática ontológica que o caracteriza; a incapacidade de romper com procedimentos teóricos limitados e distorcidos que só podem afastar dos propósitos configurados pela ética assumida.

Mas do que consiste a sintese denúncia?

A resposta está contida, também de forma breve, no mesmo Prólogo: "união de uma ética de esquerda orientada para a revolução radical com uma interpretação da realidade de tipo tradicional e convencional". ${ }^{30}$

O estudo da colocação é inteiramente distinto da natureza alusiva de uma mera fórmula expressiva: sua crítica incide sobre os dois pólos do amálgama — não apenas sobre a síntese de ambos — e implica complexos problemáticos de ideação, designadamente "o conjunto de atividades mentais, tão contraditório no filosófico quanto no político", ${ }^{31}$ que caracteriza o anticapitalismo romântico.

De fato, não obstante a forma sumária, Lukács faz sua análise remontar a pontos relativamente distantes, promovendo a inclusão de elementos diversificados na malha das determinações.

Principia por exemplificar o momento inicial da referida linha de pensamento com o jovem Carlyle, estágio em que "se trata realmente de uma crítica da crueldade e da anticultura do capitalismo nascente", ressaltando imediatamente a seguir que, na Alemanha, "essa atitude crítica foi se convertendo, pouco a pouco, numa apologética do atraso político-social précapitalista do império dos Hohenzollern". E para bem enfatizar o sentido dessa mutação radical, com toda elegância Lukács alude, sem o dizer, ao envolvimento germano-belicista de Thomas Mann com a Primeira Guerra Mundial, ponderando que um livro tão importante como as Considerações de um apolítico, publicado pelo romancista em 1918, superficialmente pode ser entendido como uma "obra que se move nessa mesma linha", mas que a evolução de Mann nos anos vinte justifica a caracterização que ele próprio ofereceu do texto: "É um combate de retirada em grande estilo, o último e mais tardio de uma civilização romântica-germânica, conduzido com plena consciência de sua inviabilidade (...), e compreendendo também a insalubridade anêmica e o vício de toda a simpatia por aquilo que está a morrer(...)"”. ${ }^{32}$ 
Sem dúvida, Lukács toma emprestada a força excepcional dessas frases de Mann para fustigar com o máximo rigor tanto a nostalgia romântica, quanto, com igual obviedade, a miséria alemã. Em verdade, estabelece explicitamente um contraste entre o autor de A teoria do romance e o autor de Considerações de um apolítico. Trata-se de uma confrontação frontal e levada ao extremo, uma vez que toma por medida o porte espiritual de um raro gigante da literatura do século XX. Comparação que, bem a propósito, não favorece o grande romancista; ao contrário, enquanto no escritor das Considerações ainda se manifesta, para usar suas próprias palavras, "a insalubridade anêmica e o vício de toda a simpatia por aquilo que está destinado a morrer", isto é, a nostalgia romântica pela "miséria alemã", Lukács pode categoricamente assegurar que "no autor de A teoria do romance não há nem traço de tal estado de espírito". ${ }^{33}$ O filósofo húngaro, com esse inteligente volteio, mais uma vez define o romantismo, e exibe a antigüidade de sua própria definição intelectual diante dele.

Leve-se em conta, ademais, pelo espírito e contexto da distinção lukacsiana, que não se está simplesmente em face de uma desigualdade corriqueira entre consciências individuais isoladas, mas que a contundente contraposição é formulada em conexão com o discernimento de modos também contrastantes de sofrer as heranças culturais da "miséria alemã". Enquanto Mann até a proximidade dos anos 1920, ainda que sob a forma do "último e mais tardio combate de retirada", está vinculado à "sublimação e estilização ideológica" que, após a solução prussiana da unificação, apresenta a Alemanha como "destinada a superar as contradições da democracia moderna por unidade superior", ${ }^{34}$ expressão mistificada de sua incontemporaneidade; Lukács, por outro lado, na superioridade inquestionável de sua atitude, apresenta-se, todavia, fragilizado pela debilidade do que fora a oposição iluminista à monarquia, entre a unificação e o fim da Primeira Guerra:

Na medida em que a Alemanha guilhermina teve uma literatura de oposição realmente com princípios, esta se baseou nas tradições da Ilustração, principalmente, desde logo, em seus epígonos mais triviais, e assim se situou de um modo globalmente negativo com respeito às tradições literárias e teóricas da Alemanha. ${ }^{35}$

Heranças - para cujas diferenças fundamentais não terão sido desprezíveis — o peso do laço germânico, central em Mann, e o vínculo, bem mais leve,

33 LUKÁCS. Prólogo a La Teoria de la Novela. In: Obras completas, v. I, p. 290.

34 LUKÁCS. Goethe y su época. In: Obras completas, v. VI, p. 57.

35 LUKÁCS. Prólogo a La Teoria de la Novela. In: Obras completas, v. I, p. 291. 
húngaro periférico de importação intelectual além de Lukács, que há de ter favorecido ou apressado ao segundo a compreensão da estreiteza comprometida do romantismo e do nacionalismo europeu, fazendo com que assumisse muito cedo uma postura de inquirição estética e existencial de viés aristocratizante - a espera olímpica do desmoronamento da desumanidade da capital —, mas de fina e diferenciada elaboração, que marca sua juventude, em que pesem todos os seus limites e insuficiências reais e clamorosas.

Posto em termos estritamente conceituais, isso significa que a prática lukacsiana das ciências do espírito, desde a redação de A teoria do romance, está desvinculada de qualquer pathos romântico - típico ou atípico. "Sua oposição à descultura do capitalismo não contém simpatia alguma pela miséria alemã e seus restos no presente." ${ }^{\prime 36} \mathrm{O}$ tributo pago ao conservantismo teórico está no próprio exercício da Geisteswissenschaft. Lukács é extraordinariamente preciso no tratamento da questão, que é pedra angular para o entendimento de todo seu itinerário pré e protomarxista. Seu trânsito de Kant e Hegel, dá-se, como esclarece no Prólogo de 1962, "sem mudar em nada minha relação com os métodos das ciências do espírito" ${ }^{37}$ e acrescenta que há justificativa histórica para esse problemático caminho, pois era a alternativa para "a mesquinha superficialidade do positivismo neokantiano ou de outra raiz, tanto no tratamento de personagens ou conexões históricas, quanto no dos fatos espirituais (lógica, estética etc.)". E reforça o argumento referindo "influência fascinante de Das Erlebnis und die Dichtung (Vivência e poesia, 1905) de Dilthey, livro que, de vários pontos de vista, parecia descobrir terra nova. Esse novo continente nos pareceu, então, um mundo mental de ambiciosas sínteses, teóricas e históricas". Adesão entusiástica, sem dúvida, porém acrítica, pois, "não nos demos conta do pouco que, em realidade, esse novo método superava o positivismo, e como pouco objetivamente se fundavam suas sínteses". ${ }^{38}$

Um arcabouço explicativo dessa ordem já fora explicitado, quase trinta anos antes, em Meu caminho para Marx. Vale, no entanto, sua transcrição por inteiro, não só por ser a prova do tempo da autodiagnose lukacsiana, mas também porque oferece alentos para uma visão mais integral do problema e da evolução futura do autor, particularmente no que tange à sua completa recusa do kantismo; audácia esta que veio a ser, a um tempo, fator dos mais relevantes para a configuração de sua obra, bem como o motivo inconfesso de certas iras que recolhe mais hoje do que nunca, e que não lhe perdoam ter dado as costas

36 LUKÁCS. Prólogo a La Teoria de la Novela. In: Obras completas, v. I, p. 290.

37 Ibidem, p. 282.

38 Ibidem, p. 282-283. 
à "revolução copernicana", o que desarvorou os filosofantes do século passado. Sem mais, eis as considerações que faz em 1933 a respeito de sua remota juventude:

\begin{abstract}
A tese neokantiana da "imanência da consciência" ajustava-se perfeitamente à minha posição de classe na época; não a submetia a qualquer exame crítico, mas a aceitava passivamente como ponto de partida de toda e qualquer colocação do problema gnosiológico. Na verdade, mantinha uma constante suspeita frente ao extremado idealismo subjetivo (tanto o da escola neokantiana de Marburgo quanto o da teoria de Mach), uma vez que não conseguia compreender como o problema da realidade poderia ser definido, considerando-a simplesmente como uma categoria imanente da consciência. Embora isso não tenha me conduzido a conclusões materialistas, acabou me levando muito mais a uma aproximação com aquelas escolas filosóficas que queriam resolver este problema de forma irracionalista e relativista e até, muitas vezes, mística (Windelband-Rickert, Simmel, Dilthey). (...) Seguindo o exemplo de Simmel eu, de um lado, separava o quanto possível a "sociologia" do fundamento econômico, concebido de modo bastante abstrato, e, de outro lado, via na análise "sociológica" apenas o estágio inicial da verdadeira e real pesquisa científica no campo da estética. Os meus ensaios publicados entre 1907 e 1911 oscilavam entre este método e um subjetivismo místico. ${ }^{39}$
\end{abstract}

Em suma, o perfil do conservantismo teórico está desenhado, o convencionalismo cognitivo das ciências do espírito posto em evidência. Todavia, a centralização da denúncia sobre as Geisteswissenschaften não equivale à simples reiteração crítica de um mesmo ato representativo inalterado; ao contrário, é a denúncia de uma matriz que é irradiada por muitas diversificações, integrando procedimentos compósitos pluralizados.

A variante consubstanciada em $A$ teoria do romance, por sua inflexão hegeliana, acentua diferenças e aguça contrastes, tornando ainda mais visível o alto tributo conservador pago pelos procedimentos analíticos lukacsianos à época, como põe em evidência a própria tensão anticonservadora na qual elabora o autor seu pensamento, e que aparece, por circunstância mas não por acaso, como uma luta difícil e nuanceada contra o neokantismo, conduzida contraditoriamente no interior e através da atmosfera kantiana das ciências do espírito, das quais, como já assinalado, Lukács ainda não se livrara, nem tão cedo se livrará. No Prólogo de 1962, as considerações a respeito são transparentes. Diz seu autor:

Já aludi ao fato de que o autor de A teoria do romance se havia tornado hegeliano. Os demais representantes importantes dos métodos das "ciências do espírito" se situavam num terreno kantiano não isento de restos positivistas, Dilthey principalmente. E os 
intentos de superar o racionalismo trivialmente positivista significavam quase sempre um passo ao irracionalismo; assim o fazia principalmente Simmel, mas também já o próprio Dilthey.

Ao lado disso, uma dupla heterodoxia, o cultor hegeliano das Geisteswissenschaften e a própria heterodoxia de seu hegelianismo: "Desde logo, o autor de A teoria do romance não era um hegeliano exclusivista e ortodoxo. As análises de Goethe e Schiller, as concepções do velho Goethe (o demoníaco), as teorias estéticas do jovem Friedrich Schlegel e de Solger (a ironia como meio moderno da dação de forma) completam e concretam as linhas gerais hegelianas." E, ao assinalar que no território da estética o resultado principal da renovação hegeliana fora a "historicização das categorias estéticas", argumenta muito sintomaticamente:

Os kantianos, como Rickert e sua escola, abrem um abismo metodológico entre o valor atemporal e a realização histórica dos valores. Dilthey mesmo não concebe essa contraposição de um modo tão cortante, porém, de toda maneira, não ultrapassa nunca, em seus esboços metodológicos de história da filosofia, a afirmação de uma tipologia meta-histórica das filosofias, a qual se realiza historicamente em variações concretas (...).

Para concluir centrando sobre aspectos decisivos, já postos aqui em evidência:

O fundamento desse conservadorismo filosófico é, do ponto de vista da concepção do mundo, a atitude histórico-política conservadora dos representantes principais das ciências do espírito, atitude que remete espiritualmente a Ranke e se encontra assim em violenta contraposição com a evolução dialética do espírito do mundo tal como o ensina Hegel. ${ }^{40}$

\section{Referências}

GOLDMANN, L. Introduzione a Teoria del Romanzo. Milão: Sugar Editore, 1963.

LUKÁCS, G. Dalla Prefazione a Storia dello sviluppo del Drama Moderno. In:

Scritti di Sociologia della Literatura. Milão: Sugar Editore, 1964.

. Pensamento vivido - Autobiografia em diálogo. São Paulo: Estudos e Edições

Ad Hominem; Viçosa: Editora UFV, 1999.

. Prólogo a La Teoria de la Novela. In:__ . Obras completas. Barcelona:

Ediciones Grijalbo, 1975. v. I.

. Epistolário (1902-1917). Roma: Editori Riuniti, 1984.

40 LUKÁCS. Prólogo a La Teoria de la Novela. In: Obras completas, v. I, p. 285-286. 
LUKÁCS, G. Prólogo (1967) a Histora y Consciência de Clase. México D. F.: Editorial Grijalbo, 1969.

Meu caminho para Marx. In: .Marx Hoje. 3. ed. São Paulo: Editora Ensaio, 1988. v. 1 (Cadernos Ensaio - Série Grande Formato).

Goethe y su época. In: . Obras completas. Barcelona: Ediciones Grijalbo, 1968. v. VI.

TERTULIAN, N. L'évolution de la pensée de Georg Lukács. L'Homme et la Societé, Paris: Editions Anthropos, n. 20, p. 15, avril,-mai-juin, 1971. 